\title{
Histological Study of the First Seven Days of Skin Wound Healing in Rats
}

\author{
${ }^{1}$ B. VIDINSKÝ, ${ }^{1}$ P. GÁL, ${ }^{1}$ T. TOPORCER, ${ }^{2}$ F. LONGAUER, ${ }^{3}$ L. LENHARDT, ${ }^{2} \mathrm{~N}$. BOBROV ${ }^{1} \mathrm{~J}$. SABO \\ ${ }^{1}$ Department of Medical Biophysics, Faculty of Medicine, Pavol Jozef Šafárik University in Košice \\ ${ }^{2}$ Department of Forensic Medicine, Faculty of Medicine, Pavol Jozef Šafárik University in Košice \\ ${ }^{3}$ Department of Pathological Anatomy, Physiology and Genetics, University of Veterinary Medicine, Košice, \\ Slovak Republic
}

Received October 6, 2005

Accepted March 16, 2006

\begin{abstract}
Vidinský B., P. Gal, T. Toporcer, F. Longauer, L. Lenhardt, N. Bobrov, J. Sabo: Histological Study of the First Seven Days of Skin Wound Healing in Rats. Acta Vet. Brno 2006, 75: 197-202.

The aim of this study was to elaborate a histological model of incisional skin wound healing in Sprague-Dawley rats. Under aseptic conditions two paravertebral full thickness skin incisions were performed on the back of 42 anesthetized male rats. Histological sections from tissue specimens were stained by hematoxylin and eosin, van Gieson, PAS + PSD, Mallory's phosphotungstic hematoxylin and azur and eosin and evaluated during the first seven days after surgery. Histological evaluation revealed that the regeneration of injured epidermis was completed five days after surgery. The inflammatory phase was recorded during the first three days of healing with the culmination of this phase between day one and day two. The beginning of the proliferative phase was dated to the first day and the peak during day five and day six. The initiation of the maturation and remodeling phase of the healing process was observed six days after wounding. At the layer of striated muscle, the centronucleated cells were described for the first time six days after surgery. The wound healing process of rat skin was histologically described during the first seven days. Results of this work can serve as an experimental model for further research using external pharmacological and physical factors (laser light, magnetic field) by which the wound healing can be favourably influenced.
\end{abstract}

Sprague-Dawley rats, inflammatory phase, proliferative phase, maturation in remodeling phase, histology

Wound healing is one of the most complex biological events after birth (Gillitzer et al. 2001). It is a complex process of the replacement of dead tissue by a vital tissue (Rubin et al. 1994). The response of the body to local injury begins very early in the process of inflammation, and results in repair and regeneration. Regeneration is a replacement of injured tissue by parenchymal cells of the same type, sometimes leaving no residual trace of the previous injury (Kumar et al. 2003). Repair is a replacement by connective tissue, which in its permanent state constitutes a scar (Menetrey et al. 2000). Tissues of mammals consist of a mixture of cells that includes three types: permanently dividing - labile cells (e. g. epithelial cells), cells that occasionally go back to the cell cycle - stabile cells (e. g. fibroblasts, satellite cells) and non-dividing cells (e. g. striated muscle cells) (Ku mar et al. 2003). The rat skin structure is, in many aspects, similar to human skin. The specific structural characteristics may vary depending on the body region (Marcelo et al. 2003). The skin of the dorsum of a normal rat is formed by epidermis, dermis and subcutaneous striated muscle. The epithelial appendages are mostly hair follicles and sebaceous glands. However, no sweat glands were observed in rats (Marcelo et al. 2003). Hair follicles can play a role in the process of epithelization. If some hair follicles are placed in the incisional space, they can serve as other centers of epithelization. Therefore we could study the 
healing of three different tissue types (due to ability of proliferation) - epidermis, dermis and striated muscle.

Only the epidermis has the capability to regenerate. A wound healing of injured dermis runs in three basic phases: inflammation, proliferation and maturation (Barbul and Regan 1993). The phases are not strictly separated from each other, their processes freely blend together. The healing process of injured striated muscle includes three phases: the destruction phase, the repair phase and the remodeling phase (Menetrey et al. 2000). During the repair and remodeling phase of muscle healing, there are two concurrent processes that are at the same time supportive but also competitive with each other (Järvinen et al. 2005). The first process is the differentiation of new myofibers from satellite cells. The second one is the formation of the granulation and scar tissue, which serve as a scaffold for regenerating myofibers. This is very similar to the healing of injured dermis.

The most preferable models in evaluating the effects of various factors improving the process of wound healing during the years 2000-2003 are the incisional (38.2\%), excisional $(38.2 \%)$ and burns (18.8\%) (Dorsett-Martin 2004). So the aim of this work was to elaborate a histological study of wound healing in rat skin as a basis for further research. Wound healing needs to be understood so that the patient's care may be optimized.

\section{Materials and Methods}

This experiment was approved by the Ethical Committee of the Faculty of Medicine of P.J. Šafárik University in Košice and by the State Veterinary Administration of the Slovak Republic. Male, 5-7-month-old SpragueDawley rats weighing about 450 - $550 \mathrm{~g}$ were used in this study. After a one-week acclimatization period 42 rats were randomly divided into seven groups of six animals each. The animals were fed a standard laboratory diet and had access to drinking water ad libitum.

A combination of ketamine ( $40 \mathrm{mg} \cdot \mathrm{kg}^{-1}$, Calypsol, Chemical Works of Richter Gedeon Ltd., Hungary), xylazine (15 mg.kg-1 , Rometar a.u.v., Spofa a.s., Czech Republic) and tramadol (5 mg.kg ${ }^{-1}$, Tramadol-K, Krka d. d., Novo mesto, Slovenia) was intramuscularly injected to anesthetize the animals. Atropin was used as premedication ( 0.05 $\mathrm{mg} \cdot \mathrm{kg}^{-1}$ s.c., Atropin, Hoechst-Biotika s.r.o., Slovakia).

Two $3.5 \mathrm{~cm}$ long parallel full thickness skin incisions were performed under aseptic conditions on the left and right side of the experimental rat spine and immediately sutured by 4 simple sutures (Chiraflon 3/0, Chirmax a.s., Czech Republic). The wounds were $4 \mathrm{~cm}$ distant from each other.

Rats were sacrificed by ether inhalation. The skin wounds were removed from the body after $24 \mathrm{~h}$ (group 1 ), $48 \mathrm{~h}$ (group 2), $72 \mathrm{~h}$ (group 3), $96 \mathrm{~h}$ (group 4), $120 \mathrm{~h}$ (group 5), $144 \mathrm{~h}$ (group 6) and $168 \mathrm{~h}$ (group 7). The tissue specimens were processed routinely for light microscopy (fixating, dehydrating, embedding, cutting, staining with hematoxylin-eosin - HE, van Gieson - VG, PAS + PSD, Mallory's phosphotungstic hematoxylin - WF and azur and eosin - AZ).

Six animals (i.e. 12 wounds) were evaluated in each group. We were interested in the following morphological changes - epithelization, keratinization of epidermis, presence of inflammatory cells (PMNL, tissue macrophages), creation of fibrin network, migration and proliferation of fibroblasts, creation of new extracellular matrix - ECM (especially new collagen fibers), neoangiogenesis and repair of damaged striated muscle (presence of centronucleated cells). Semi-quantitative method was used for evaluation of histological sections. The microscopic structures and changes (epithelization, PMNL, tissue macrophages, fibroblasts, neoangiogenesis, new collagen fibers and centronucleated cells) were evaluated. The following scale was used: in epidermis ( 0 - thickness of cut edges, 1 - migration of epithelial cells, 2 - bridging of the incision, 3 - complete regeneration), in dermis and striated muscle layer ( 0 - absent, 1 - mild, 2 - moderate, 3 - marked). The sections were coded and blinded to the observer performing the evaluation. Average values with standard deviations were calculated for each semi- quantitatively evaluated histological structure and changes, respectively (Table 1).

\section{Results}

During the post-surgery period, the animals remained healthy, without clinical evidence of infection. The microscopic observation also confirmed the aseptic conditions during the wounding in all groups.

In group 1 the intense inflammatory reaction was dominant. On the surface, necrosis of skin tissue was situated as a consequence of mechanical damage. The beginning of the formation of the demarcation line (Plate V, Fig. 1-a) was observed under the tissue necrosis. 
Table 1. Semi-quantitative evaluation of histological changes/structures during skin wound healing in rats (values are presented as mean \pm standard deviation)

\begin{tabular}{|cccccrcc|}
\hline Group & Epithelization & PMNL & $\begin{array}{c}\text { Tissue } \\
\text { macrophages }\end{array}$ & Fibroblasts & $\begin{array}{c}\text { Neo- } \\
\text { angiogenesis }\end{array}$ & $\begin{array}{c}\text { New } \\
\text { collagen }\end{array}$ & $\begin{array}{c}\text { Centro- } \\
\text { nucleated } \\
\text { cells }\end{array}$ \\
\hline 1 & $0.0 \pm 0.0$ & $1.8 \pm 0.7$ & $1.2 \pm 0.4$ & $0.7 \pm 0.7$ & $0.0 \pm 0.0$ & $0.0 \pm 0.0$ & $0.0 \pm 0.0$ \\
2 & $0.8 \pm 0.5$ & $2.2 \pm 0.7$ & $1.7 \pm 0.5$ & $1.8 \pm 0.5$ & $1.2 \pm 0.7$ & $0.0 \pm 0.0$ & $0.0 \pm 0.0$ \\
3 & $1.8 \pm 0.4$ & $1.3 \pm 0.7$ & $1.9 \pm 0.7$ & $2.0 \pm 0.4$ & $1.7 \pm 0.5$ & $0.6 \pm 0.5$ & $0.0 \pm 0.0$ \\
4 & $2.2 \pm 0.4$ & $0.4 \pm 0.7$ & $1.4 \pm 0.1$ & $2.3 \pm 0.5$ & $2.0 \pm 0.7$ & $1.6 \pm 0.5$ & $0.0 \pm 0.0$ \\
5 & $2.6 \pm 0.5$ & $0.2 \pm 0.4$ & $1.3 \pm 0.7$ & $2.8 \pm 0.5$ & $2.6 \pm 0.5$ & $2.2 \pm 0.4$ & $0.2 \pm 0.4$ \\
6 & $2.8 \pm 0.4$ & $0.1 \pm 0.3$ & $1.3 \pm 0.6$ & $2.9 \pm 0.3$ & $2.9 \pm 0.3$ & $2.8 \pm 0.5$ & $0.6 \pm 0.5$ \\
7 & $3.0 \pm 0.0$ & $0.0 \pm 0.0$ & $1.1 \pm 0.3$ & $3.0 \pm 0.0$ & $2.4 \pm 0.5$ & $3.0 \pm 0.0$ & $1.2 \pm 0.4$ \\
\hline
\end{tabular}

Thus the cellular reaction of inflammatory phase was initiated. The demarcation line consisted of polymorphonuclear leukocytes (PMNL) (1.8 \pm 0.7$)$. Macrophages concomitantly invaded the wound area $(1.2 \pm 0.4)$. The epidermis was thickened at its cut edges (Plate V, Fig. 1-b) as a result of mitotic activity of basal cells. The fibrin network filled out the incisional space, which was confirmed by WF staining. This network contained blood cells and created a scaffold for migrating fibroblasts $(0.7 \pm 0.7)$. The striated muscle showed necrotic myofibers in the deepest part of the wound.

In group 2 it was possible to observe that necrotic debris on the surface was almost removed and the scab was forming (Plate V, Fig. 2-b). Mainly from the thickened edges of epidermis, keratinocytes migrated beneath the scab (Plate V, Fig. 2-a), but never bridged the whole incision $(0.8 \pm 0.5)$. We also recorded the reepithelization from hair follicles. The inflammatory infiltrate persisted but the proportion of inflammatory cells was changed. PMNL $(2.2 \pm 0.7)$ were replaced by tissue macrophages $(1.7 \pm 0.5)$. Fibroblasts were randomly distributed near the incisional space $(1.8 \pm 0.5)$. Azur and eosin and van Gieson stainings revealed red blood cells in the loops of new synthesized capillaries (1.2 \pm 0.7$)$. PAS staining confirmed the synthesis of new extracellular matrix (ECM) mainly at the layer of striated muscle. However, the specific staining for collagen fibers (VG) was not positive. The main role in the process of degradation of necrotic myofibers had macrophages. They were almost always present in wounds during the first week of the healing process.

The histological analysis in group 3 demonstrated the retirement of inflammatory process. The inflammatory phase was almost completed, PMNL were only randomly dispersed near the incisional space $(1.3 \pm 0.7)$ and the number of macrophages were maintained on the same level as in group $2(1.9 \pm 0.7)$. The reepithelization rapidly continued. The incisions were completely bridged with 3 layers of newly synthesized epithelial cells $(1.8 \pm 0.4)$. Additionally, the differentiation process of keratinocytes was confirmed by the appearance of keratin layer (the cells without nucleus) above the epithelial layers with nuclear cells. The formation of granulation tissue was mainly situated on the bottom of the wounds where moderate number of fibroblasts $(2.0 \pm 0.4)$ and increasing number of new capillaries $(1.7 \pm 0.5)$ were present (Plate V, Fig. 3-a). The incisional space at the layer of dermis and striated muscle contained an extracellular matrix without a significant quantity of collagen, which was verified by VG staining. The new collagen fibers in granulation tissue were placed only in focal areas $(0.6 \pm 0.5)$.

The healing period four days after surgery was characterized by almost total regression of the inflammatory process. This reduction was confirmed by the number of PMNL, the major marker of acute inflammation. If those cells were present, they were found only sparsely distributed $(0.4 \pm 0.7)$. Reepithelization showed a higher number of newly formed epithelial layers and also the differentiation of nuclear keratinocytes to keratinized cells was continued. At the layer of dermis fibroblasts were predominantly vertically oriented, 
however, in granulation tissue, between the edges of striated muscle; they did not exhibit any organization pattern $(2.3 \pm 0.5)$ (Plate V, Fig. 4-a). The angiogenesis revealed a considerable number of new vessels $(2.0 \pm 0.7)$. An increase in the amount of ECM was found in PAS-stained slides. VG showed that in this period collagen fibers were in disorganized arrangement placed as small randomly distributed fibrils $(1.6 \pm 0.5)$. At the layer of striated muscle, the formation of granulation tissue continued simultaneously with the processes at the layer of dermis. Still the degenerating myofibers were observed. We did not find any centronucleated cells, which were considered as regenerating myofibers.

Histological sections from the five days of healing wounds showed a completely finished reepithelization process. The thickness of epidermis was similar to intact epidermis $(2.6 \pm$ $0.5)$. This time period showed a typical histological picture of the proliferative phase with expressive representation of fibroblasts and new vessels. They were mostly situated at the layer of striated muscle in granulation tissue. The granulation tissue also consisted of ECM, which was visualized by PAS staining as a PAS positive substance (Plate V, Fig. 5-a). The marked presence of new collagen fibers was verified by VG staining. They were disorganized and filled out the space between cells in granulation tissue. As compared to earlier periods of healing, they presented the major component of ECM. A marked number of new created vessels were seen on AZ and VG-stained slides $(2.6 \pm 0.5)$. No changes in organization pattern of fibroblasts were recorded. Important but not significant histological changes were observed in striated muscle layer. The centronucleated cells appeared in the bordering areas of muscle stumps $(0.2 \pm 0.4)$.

The microscopic observation from histological sections in groups 6 and 7 revealed similar histopathological findings regarding the reepithelization process and amount of granulation tissue. For these time periods remodeling and reorganization of ECM and fibroblasts was characterized. In group 6 still vertically oriented fibroblasts were described $(2.9 \pm 0.3)$. However, in group 7 for the first time fibroblasts significantly changed their orientation, they were mostly parallel to the basement membrane $(3.0 \pm 0.0)$. In comparison to previous groups (group $6-2.8 \pm 0.5$, group $7-3.0 \pm 0.0$ ) the red coloration of collagen fibers in VG staining was more intense. It also revealed more bundles of collagen fibers and not only fibers sparsely distributed. In group 7 collagen fibers exhibited more evident organization pattern (Plate V, Fig. 7-a). We recorded mild regress in the number of new capillaries (group $6-2.9 \pm 0.3$, group $7-2.4 \pm 0.5$ ). This decrease could be a result of gradually continuing remodeling phase. Centronucleated cells were situated in areas near the muscle stumps (group $6-0.6 \pm 0.5$ ) and their number increased only slightly (group $7-1.2 \pm 0.4$ ).

In summary, after seven days of healing, all animals exhibited completely finished reepithelization, disappearance of acute inflammatory signs, and reorganization of granulation tissue devoid of cutaneous attachments as well as the presence of regenerating myofibers.

\section{Discussion}

The wound healing process of rat skin was histomorphologically and chronologically described during the first seven days. Other studies evaluated histologically only certain time intervals, i.e. the seventh day by Menetrey et al. (2000), the fourth and seventh day by Rasik et al. (1996), the second, fourth, seventh and fourteenth day by Whelan et al. (2003) and the first, third, fifth, seventh and tenth day by Connolly et al. (1997) and they observed an influence of various factors on the wound healing. Our study correlates with other studies researching histomorphologically the wound healing process (per primam intentionem) of the rat skin (Amadeu er al. 2003; Marcelo et al. 2003; Medrado et al. 2003; Menetrey et al. 2000; Rasik et al. 1996). The most significant morphological changes occur during the first seven days of wound healing (Burkitt et al. 1990) and this 
contributes to the importance of our study. During this period there is the best possibility to influence this process by pharmacological factors - oleo-resin from Copaifera langsdorffi (Paiva et al. 2002), allopurinol (Prada et al. 2002) or sildenafil citrate (Tao et al. 2003) and physical factors - magnetic fields (Milgram et al. 2004) or low level laser therapy (Stadler et al. 2001; Gál et al. 2005ab).

The healing process of the three different tissue types (due to ability of proliferation) was studied. The complete regeneration of the rat epidermis was finished on the fifth day after the surgery, which is comparable to humans (Ku mar et al. 2003). The acute inflammatory phase in rats was described in our study during the first three days of healing. In comparison with humans the process of rat inflammation is faster (Gillitzer et al. 2001; Ku mar et al. 2003). The peak of the proliferative phase in rats in our study was observed between the fifth and sixth day. In comparison with humans, this process is faster but comparable (B arbul and Regan 1993; Kumar et al. 2003). In our study the maturation and remodeling phase in rats started on the sixth day. In humans, this phase starts on the seventh day of wound healing (B arbul et al. 1993; Ku mar et al. 2003; Rubin et al. 1994). The centronucleated muscle cells were considered as regenerating myofibers. The significant number of these cells was present on day seven of healing. The number of myofibers correlates with results of a study researching influence of the growth factors on gastrocnemius muscle healing in rats (Menetrey et al. 2000) and also it is in accordance with the human muscle healing (Ku mar et al. 2003). However, the centronucleated cells were not described during the rat skin wound healing.

In conclusion, the healing of the epidermis, dermis and striated muscle in rats is faster, however, comparable to the healing of human skin and striated muscle. At the present time there is no research paper about rat skin wound healing that assesses all layers of rat skin. Therefore, results of this work can serve as an experimental model for further research using external factors by which the wound healing can be favourably influenced.

\section{Histologická štúdia prvých siedmich dní hojenia kožných rán u potkanov}

Cielom našej práce bolo vypracovat incizionálny kožný model hojenia rán u potkanov Sprague-Dawley. Za aseptických podmienok boli na chrbte 42 anestetizovaných potkanov vykonané dve paravertebrálne kožné incízie. Histologické rezy zo vzoriek kože boli farbené nasledovnými farbeniami: hematoxylín eozín, van Gieson, PAS + PSD, Malloryho fosfowolfrámový hematoxylín a azúr a eozín. Vyhodnocované boli počas prvých siedmich dní hojenia. Histologické vyšetrenie ukázalo, že regenerácia epidermis bola ukončená pät dní po operácii. Zápalová fáza bola zaznamenaná počas prvých troch dní hojenia s kulmináciou medzi prvým a druhým dňom. Začiatok proliferačnej fázy bol datovaný do obdobia prvého dňa s vrcholom medzi piatym a šiestym dňom. Začiatok maturačnej a remodelačnej fázy hojenia bol pozorovaný na šiesty deň po operácii. Proces hojenia kožnej rany u potkana bol histologicky popísaný počas prvých siedmych dní hojenia. Výsledky tejto práce môžu slúžit ako experimentálny model pre další výskum zaoberajúci sa vplyvom vonkajších farmakologických a fyzikálnych faktorov (laserové svetlo, magnetické polia), ktoré by mohli pozitívne ovplyvnit proces hojenia.

\section{Acknowledgement}

The authors wish to thank Karen Magin for language corrections and useful comments. Also we thank A. Suchá for preparing histological sections. This study was partially supported by the P. J. Šafárik University institutional grants for young scientists and students No. VVGS-56/2006 and No. VVGS-58/2006.

\section{References}

AMADEU TP, COULOMB B, DESMOULIERE A, COSTA AMA 2003: Cutaneous wound healing: myofibroblastic differentiation and in vitro models. Int $\mathrm{J}$ Low Extrem Wounds 2: 60-68 
BARBUL A, REGAN MC 1993: Biology of wound healing. In: FISCHER JA (Ed).: Surgical Basic Science. Mosby- Yearbook, St. Louis, pp. 68-88

BURKITT HG, QUICK GRG, GATT D. 1990: Essential Surgery. Churchill Livingstone, Edinbourg, London, Melstone, New York, $771 \mathrm{p}$

CONNOLLY JA, SUH YD, HUNT KT, COUGHLIN SR 1997: Mice lacking the thrombin receptor, PAR1, have normal skin wound healing. Am J Path 151: 1199-1206

DORSETT-MARTIN WA 2004: Rat models of skin wound healing: a review. Wound Rep Reg 12: 591-599

GILLITZER R, GOEBELER M 2001: Chemokines in cutaneous wound healing. J Leukoc Biol 69: 513-521

JÄRVINEN TA, JÄRVINEN TL, KAARIAINEN M, KALIMO H, JÄRVINEN M 2005: Muscle injuries: biology and treatment. Am J Sports Med 33: 745-764

KUMAR V, COTRAN RZ, ROBBINS SL 2003: Basic Pathology $7^{\text {th }}$ Ed. Saunders, Philadelphia, London, Toronto, Montreal, Sydney, Tokyo, 873 p.

MARCELO BT, KEMLI RB, CRISTIANO N, COMESU MC 2003: Progressive effects of diabetes mellitus on the skin epithelium of the rat. Int J Morphol 21: 143-148

MEDRADO AR, PUGLIESE LS, REIS SR, ANDRADE ZA 2003: Influence of low level laser therapy on wound healing and its biological action upon myofibroblasts. Lasers Surg Med 32: 239-244

MENETREY J, KASEMKIJWATTANA C, DAY CS, BOSCH P, VOGT M, FU FH, MORELAND MS, HUARD J. 2000: Growth factors improve muscle healing in vivo. J Bone Joint Surg Br 82: 131-139

MILGRAM J, SHAHAR R, LEVIN-HARRUS T, KASS P 2004: The effect of short, high intensity magnetic field pulses on the healing of skin wounds in rats. Bioelectromagnetics 25: 271-277

PAIVA LA, DE ALENCAR CUNHA KM, SANTOS FA, GRAMOSA NV, SILVEIRA ER, RAO VS 2002: Investigation on the wound healing activity of oleo- resin from Copaifera langsdorffi in rats. Phytother Res 16: 737- 739

PRADA FS, ARRUNATEGUI G, ALVES MC, FERREIRA MC, ZUMIOTTI AV 2002: Effect of allopurinol, superoxide-dismutase, and hyperbaric oxygen on flap survival. Microsurgery 22: 352-360

RASIK AM, SHUKLA A, PATNAIK GK, DHAWAN BN, KULSHRESTHA DK, SRIVASTAVA S 1996: Wound healing activity of latex of Euphorbia neriifolia Linn. Ind J Pharmacol 28: 107-109

RUBIN E, FARBER JL 1994: Pathology $2^{\text {nd }}$ Ed. J. B. Lippincot, Philadelphia, 1578 p.

STADLER I, LANZAFAME RJ, EVANS R, NARAYAN V, DAILEY B, BUEHNER N, NAIM JO 2001: $830 \mathrm{~nm}$ irradiation increases the wound tensile strength in a diabetic murine model. Lasers Surg Med 28: 220-226

TAO A, ATASOY N, ÖZBEK H, ASLAN L, YÜKSEL H, CEYLAN E, DAGOGLU G 2003: The effects of sildenafil citrate (Viagra) in the early phase of healing process in open wounds in dogs. Acta Vet Brno 72: 273-277

WHELAN HT, BUCHMANN EV, DHOKALIA A, KANE MP, WHELAN NT, WONG- RILEY MT, EELLS JT, GOULD LJ, HAMMAMIEH R, DAS R, JETT M 2003: Effect of NASA light-emitting diode irradiation on molecular changes for wound healing in diabetic mice. J Clin Laser Med Surg 21: 67-74 
Plate V

Vidinský B. et al.: Histological Study ... pp. 197-202

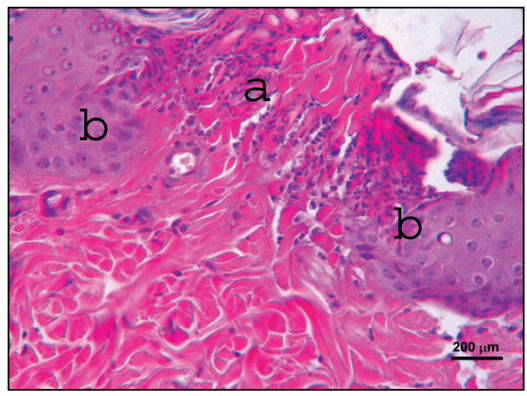

Fig. 1. Skin wound after 24 hours of healing (hematoxylin-eosin staining, $\times 200$ ). The line of demarcation (a). Thickened edges of epidermis (b).

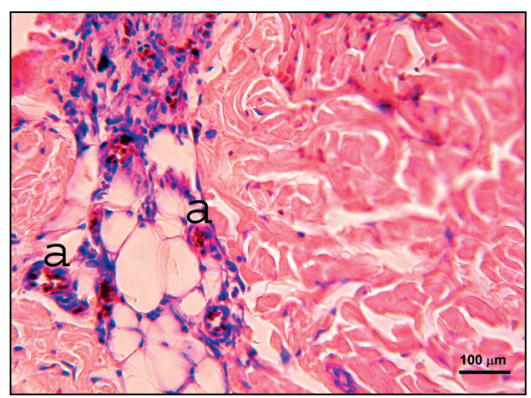

Fig. 3. Skin wound after 72 hours of healing (azur and eosin staining, $\times 400$ ). New capillaries (a).

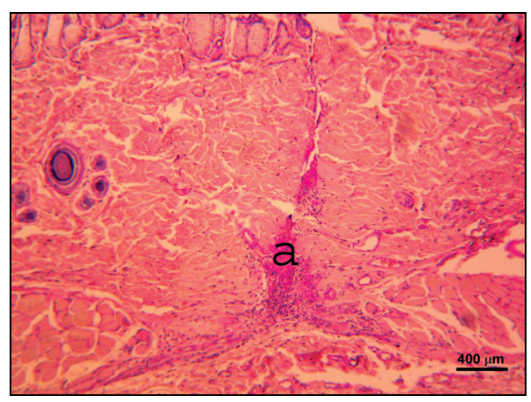

Fig. 5. Skin wound after 120 hours of healing (PAS staining, $\times 100)$. Great amount of new ECM (a).

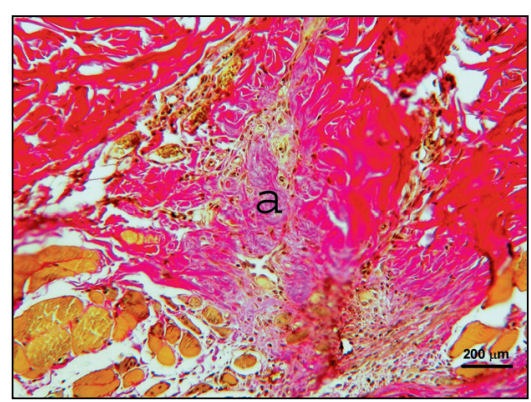

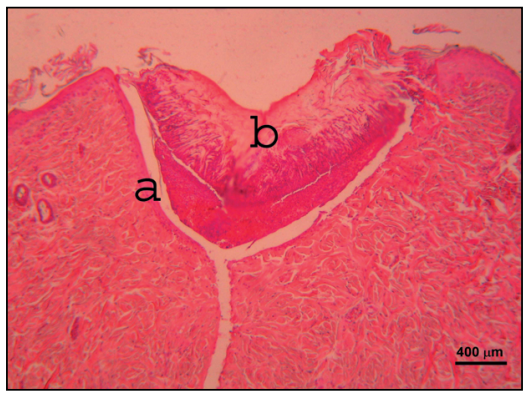

Fig. 2. Skin wound after 48 hours of healing (hematoxylin-eosin staining, $\times 100$ ). Migration of epithelial cells (a). Scab forming (b).

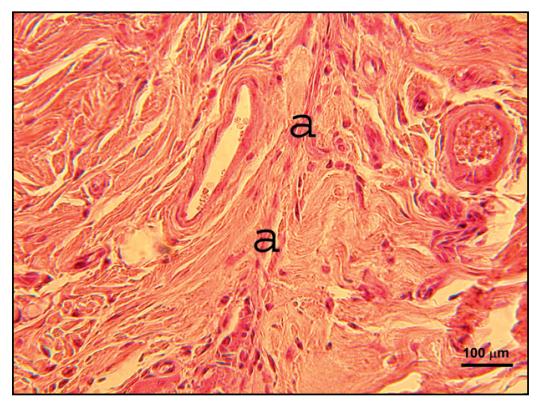

Fig. 4. Skin wound after 96 hours of healing (hematoxylin-eosin, $\times 400$ ). Fibroblasts longitudinally to the incision (a).

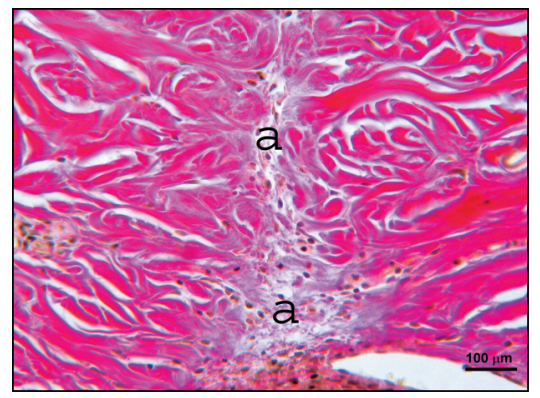

Fig. 6. Skin wound after 144 hours of healing (van Gieson, $\times 200)$. Collagen fibers bridged the incision (a).

Fig. 7. Skin wound after 168 hours of healing (van Gieson, $\times 200$ ). Increase of granulation tissue capillaries (a). 